\title{
O FIM É O REMÉDIO
}

Ophélia Brown ${ }^{1}$

Se você está por perto

Meu mundo se faz completo

Sem sua presença

Tudo é frio e sombrio

Eu não existo sem ti

Meus dias não têm cor

Teu silêncio mordaz

Dilacera a minha carne

Corta minhas entranhas

Tudo dói

A dor corrói

$\mathrm{O}$ ar me falta

Sem teus olhos em minha direção

Seu sorriso para um outro alguém...

Ferida que não cicatriza

Quanto mais oculta

Mais sangra

É veneno

Sem soro

Que me inunda

É remédio

O canto da sereia

Encanta

Deprime

Fere

Sangra

${ }^{1}$ Heterônimo de Danielle Melchiades - afinadodesconcerto.com.br. 
Jaz aqui quem cansou

De sentir dor

E buscou como alívio

$\mathrm{O}$ acalento da morte gélida. 